tempted away by other organizations if they belonged to a pool in which high-risk people were insured on the same terms.

But that does not mean that there is nothing to be said about insurance. Companies should not be allowed to walk away from contracts when previously cryptic information comes to light and should be prevented from making panicky decisions on the basis of a little genetic screening. But these are regulatory, not ethical questions. The outstanding question is an ancient one: that of whether society at large has an obligation to be the insurer of last resort to the otherwise uninsurable. It lies at the boundary not between ethics and biology, but between ethics and the politics of social welfare.

The eugenic issue is for the time being beyond the frontier of the possible, but is certain to be widely argued. Should people, individually, as couples or in groups, be encouraged or even allowed to use genetic information to improve the genetic quality of their offspring? Naive or malevolent ambitions of this kind (Galton and Hitler respectively) have rightly acquired a bad name, but we forget that most people are in a small way eugenicists. That, no doubt, is the biological intention of parents' frequent expressions of disapproval of their children's mates (often on the basis of spurious pointers - religious belief, for example). In the same spirit, careful parents attend to the quality of their children's diet. With the advent of genetic counselling and amniocentesis, it has become possible to avoid with a high degree of certainty the occurrence of particular genetic defects in the next generation (which may still carry the affected genes).

So would it not be preferable to manipulate the germ-line so as to remove unwanted mutations from extended families once and for all? What if it were feasible, for example, safely to replace the mutated by the normal globin gene in those carrying the sickle-cell anaemia trait? The standard answer, with which the scientific community seems to agree, is that the manipulation of the human germ-line, or even part of it for which a consenting couple may be responsible, is in all circumstances out of bounds. But can that position be reasonable? To be sure, those electing for such a procedure would have to be reasonably certain that there would not be a recurrence of world-wide malaria, so that the benefits of the relative immunity of heterozygotes for the sickle-cell anaemia substitution would not be lost; second-guessing the interests of future generations raises ethical questions, but questions already familiar in matters such as the provision of public education. But in principle (and if feasible) germ-line manipulation would seem to have the ethical edge over the practices now followed.

Not much of this argument is very new, but much of it is unpopular. Over the past few years, it has become politically correct to avoid the strongest arguments in favour of the accumulation and use of genetic knowledge for fear of giving offence - or of providing out-and-out opponents of understanding with ammunition in their struggle against innovation. But in the long run, the outcome is a position weakened by what will later seem like misrepresentation. If, in a few years, there should be a strong case for observing embryos after 14 days, it will be more difficult to get the present British legislation changed than to have had it put in place at the outset. But the more serious weakness of the politically correct position is that it invests the new biology with an air of ethical daring that sometimes is inappropriate (as with genetic manipulation in the laboratory, which is a health and safety issue) and that often conceals long-standing political and social issues that merit attention in their own right).

\section{Third party assurance?}

The Liberal Democrats in Britain have made a worthy but unconvincing pass at putting science to rights.

THE policies for British science laid out in the Liberal Democrats' Green Paper (consultative document) Science and Survival are surprisingly unimaginative for a party whose chances of victory in the next British general election are so small. While the party recognizes the hostility of the post-Thatcherite climate towards innovative science, its proposed solutions are themselves a little flaccid.

The green paper claims to see the efficient utilization of Britain's scientific resources as "the only way" of reversing the country's economic slide. Such a desperate and clear-cut situation, however, seems not to be desperate enough to have persuaded the party to the reinstitution of a science minister to oversee Britain's return to the top of the world's charts. "The cabinet", the group believes, "is already too large and ... such a solution risks sweeping the issues that need to be addressed under the carpet."

Instead, the green paper proposes a cabinet committee, chaired by the prime minster, to "mastermind" the implementation of its policies. Essentially, these constitute a move away from the short-termism and general stinginess of present mechanisms for scientific funding towards a more "diffusion oriented" system, whereby innovation would be supported by industry, government and banks - all converted to appreciate the crucial role of science in the country's economic renaissance.

It is certainly a nice idea, as the policies of Liberal Democrats tend to be. It is also right and proper that it should begin with a strong argument that Britain needs a better educational system, but investment in education takes time to produce results; squaring that circle will not be easy. But this latest document lacks the conviction that might have earned the votes of the scientific community. The subtle distinction between being underfunded and being underpaid is one that the Liberal Democrats might with profit address if they ever decide to give these issues another shot. 